\title{
Aktualisasi Nilai-nilai Multikultural dalam Pembelajaran PAI dalam Kerangka Pengembangan Kebangsaan Terhadap Siswa di SMA Kharisma Bangsa
}

\author{
Jimatul Arrobi ${ }^{1 *}$, Mariana Panji Ramadan ${ }^{2}$, Anjarsari $^{3}$ \\ ${ }^{1}$ Sekolah Tinggi Agama Islam (STAI) Sukabumi, Indonesia \\ ${ }^{2}$ Sekolah Tinggi Agama Islam (STAI) Sukabumi, Indonesia \\ ${ }^{3}$ Sekolah Tinggi Agama Islam (STAI) Sukabumi, Indonesia \\ * Corresponding Author. E-mail: ${ }^{1}$ jimatularrobi94@gmail.com
}

Receive: 03/02/2021

Accepted: 20/02/2021

Published: 01/03/2021

\begin{abstract}
Abstrak
Saat ini multikulturalisme menjadi isu penting, terutama setelah serangkaian konflik yang sering terjadi di negara ini dalam beberapa tahun terakhir. Beranjak dari masalah tersebut, maka memulai pemahaman yang lebih tentang inklusif, pluralistik, dan toleran menjadi keharusan; berharap kasus-kasus seperti konflik sosial yang mengarah pada anarki atas nama SARA (Suku, Agama, Ras, Kelas), dan kepentingan lain yang menyelinap di belakangnya, tidak terulang di masa depan. Masalah-masalah ini tentu saja tidak hanya berkaitan dengan masalah bagaimana kita mengelola konflik, keragaman, dan pengakuan politis tentang perbedaan. Namun, lebih dari itu, multikulturalisme itu dapat dipahami sebagai "kepercayaan" terhadap normalitas dan penerimaan keanekaragaman. Untuk itu, salah satu cara paling efektif untuk menumbuhkan pemahaman yang lebih inklusif, pluralis, dan toleran adalah melalui proses pembelajaran. Penelitian ini diberi judul Aktualisasi nilainilai multikultural dalam pembelajaran Pendidikan Islam dalam Kerangka Pengembangan Kebangsaan di Sekolah Menengah atas Siswa Kharisma Bangsa Hasil yang diperoleh dalam penelitian ini menunjukkan bahwa ada pengaruh yang signifikan antara penerapan nilai-nilai multikultural terhadap pengembangan kebangsaan siswa di SMA Kharisma Bangsa. hal ini dibuktikan dengan perolehan nilai $r$ yang hitung sebesar 0,240, dan $r$ tabel sebesar 0,235 dan termasuk dalam kategori rendah ( $r$ hitung dalam kisaran 0,20 hingga 0,39) dengan KD 5,7.
\end{abstract}

Kata Kunci: Kebangsaan, Multikultural, Pembelajaran PAI.

\section{Actualization of Multicultural Values in PAI Learning in the Framework of National Development for Students at Kharisma Bangsa High School}

\begin{abstract}
Currently, multiculturalism has become an important issue, especially after a series of conflicts that have often occurred in this country in recent years. Moving on from these problems, starting a more inclusive, pluralistic, and tolerant understanding is imperative; hope that cases such as social conflicts that lead to anarchy in the name of SARA (Ethnicity, Religion, Race, Class), and other interests that sneak up behind it, will not be repeated in the future. These problems, of course, are not only related to how we manage conflict, diversity,
\end{abstract}


Jurnal Edumaspul, 5 (1), Year 2021 - 751

(Jimatul Arrobi, Mariana Panji Ramadan, Anjarsari)

and the political recognition of difference. However, more than that, multiculturalism can be understood as a "belief" in normality and acceptance of diversity. For this reason, one of the most effective ways to foster a more inclusive, pluralist, and tolerant understanding is through the learning process. This research is entitled Actualization of multicultural values in Islamic education learning in the framework of national development in high school students of Kharisma Bangsa. . this is evidenced by the acquisition of the calculated $r$ value of 0.240 , and the $r$ table of 0.235 and is included in the low category (counted $r$ in the range of 0.20 to 0.39) with a KD of 5.7.

Keywords: Nationality, Multicultural, PAI Learning.

\section{Pendahuluan}

Masyarakat Indonesia adalah masyarakat majemuk atau plural society. Dari segi etnis, misalnya ada suku Melayu dan ada suku Melanesia yang selanjutnya membentuk seratus suku besar dan 1.072 suku-suku derivative besar dan kecil. Dari segi bahasa, terdapat ratusan bahasa yang digunakan di seluruh wilayah Nusantara. Dari segi pulau yang dihuni, terdapat sekitar 17.504 lingkungan kehidupan kepulauan. Dari segi sejarah politik lokal, terdapat puluhan bahkan ratusan sistem kerajaan bahkan kesukuan lama yang berpengaruh terhadap sistem stratifikasi sosial dan adat istiadat setempat. Dari segi mata pencaharian terdapat keragaman antara kehidupan pedesaan dan perkotaan. Dari segi agama terdapat sejumlah agama besar dunia dan sejumlah sistem kepercayaan lokal yang tersebar di seluruh wilayah Nusantara (Atho Mudzar, 2005). Hal tersebut menunjukan kekayaan dan keberagaman yang dimiliki Indonesia tidak hanya dari segi sukunya saja tetapi dari banyak hal lainnya.

Pandangan dunia "multikultural" secara substantif sebenarnya tidaklah terlalu baru di Indonesia. Sebagai negarabangsa yang menyatakan kemerdekaannya sejak lebih setengah abad silam, Indonesia sebenarnya telah memiliki dan terdiri dari sejumlah besar kelompok etnis, budaya, agama, dan lain-lain, sehingga negarabangsa Indonesia secara sederhana dapat disebut sebagai masyarakat "multikultural" (Zakiyuddin Baidhawy, 2005). Realitas sosial Masyarakat Indonesia semacam itu sangat sulit dipungkiri dan diingkari. Untuk itu, keragaman, atau kebhinekaan, atau multikulturalisme merupakan Salah satu realitas utama yang dialami masyarakat dan kebudayaan di masa silam, lebih-lebih lagi di masa kini dan di waktu-waktu mendatang.

Keragaman etnis dan ras merupakan kenyataan yang harus diterima oleh umat manusia. Adanya pluralitas etnis dan ras, tentunya tidak harus membuat manusia yang berasal dari etnis dan ras yang berbeda menjadi terpecah belah dan saling memusuhi. Menurut Ritzer dalam Ainul Yaqin menjelaskan bahwa keragaman etnis yang terbentuk dari definisi sosial dan bukan merupakan definisi berdasarkan pada faktor keturunan/biologis, dan ras yang didefinisikan secara sosial berdasarkan berbagai macam karakteristik kulturnya (bahasa, agama, asal suku atau asal Negara, tata hidup sehari-hari, makanan pokok, cara berakaian, atau ciriciri kultur yang lainnya) bukan untuk mengukur tingkat keberbedaan dan saling melemahkan. Keberbedaan tersebut dimaksudkan agar saling kenal mengenal dengan segala dimensi keunikan dan kekayaan budaya yang dimiliki manusia. Dari beberapa keberbedaan tersebut tetap ada sifat-sifat universal yang dimiliki manusia. Dengan keuniversalan tersebut mereka mampu berempati dan bersimpati, sehingga mampu memahami "keberbedaan" orang lain di luar dirinya dengan berbagai keragaman budaya 
Jurnal Edumaspul, 5 (1), Year 2021 - 752 (Jimatul Arrobi, Mariana Panji Ramadan, Anjarsari)

(cultural diversity) (Zakiyuddin Baidhawy, 2005).

Selain itu mengenai keragaman ini di dalam Al-Qur'an dijelaskan, sebagaimana yang tertuang dalam firman Allah Q.S Al-Hujurat ayat 13 yang artinya : "Hai manusia, sesungguhnya Kami menciptakan kamu dari seorang laki-laki dan seorang perempuan dan menjadikan kamu berbangsa- bangsa dan bersuku-suku supaya kamu saling kenal-mengenal. Sesungguhnya orang yang paling mulia diantara kamu disisi Allah ialah orang yang paling takwa diantara kamu. Sesungguhnya Allah Maha Mengetahui lagi Maha Mengenal." (Q.S Al-Hujurat [49] : 13) (Departemen Agama RI, Al-Qur'an dan Terjemahannya).

Ayat ini menurut penuturan para mufasirin secara substansial menegaskan keberagaman umat manusia dari berbagai sisi. Dalam konteks Al-Qur'an diturunkan untuk mencerminkan keragaman manusia secara geografis, sementara dalam konteks saat ini mewakili keragaman geo-politik, kultural maupun Negara bangsa (nationstate) (Heru Suparman, 2017).

Secara sederhananya multikultural dapat dipahami sebagai pengakuan, bahwa suatu Negara atau masyarakat adalah memang beragam dan majemuk. Dengan demikian, multikulturalisme dapat dipandang sebagai landasan budaya (Cultural Basis) tidak hanya bagi kewargaan dan kewarganegaraan, tetapi juga bagi pendidikan (Heru Suparman, 2017).

Pendidikan menjadi salah satu kunci penting sebagai instrument membangun peradaban manusia dan bangsa. Keberadaannya masih diyakini mempunyai peran besar dalam membentuk karakter individu-individu yang dididiknya, dan mampu menjadi "guiding light" bagi generasi muda penerus bangsa. Hal tersebut dengan suatu pertimbangan, bahwa salah satu fungsi pendidikan adalah untuk meningkatkan keberagamaan peserta didik dengan keyakinan agama sendiri, dan memberikan keterbukaan untuk mempelajari dan mempermasalahkan agama lain sebatas untuk menumbuhkan sikap toleransi (Syamsul Maarif, 2019).

Selain itu, diletakkannya pendidikan agama dalam konteks pendidikan Nasional di Indonesia adalah suatu hal yang sangat penting, karena itu bangsa Indonesia dikenal dengan bangsa yang religius. Hal ini juga tercermin dalam sila pertama Pancasila. Dalam sila pertama Pancasila yang berbunyi "Ketuhanan Yang Maha Esa" hal tersebut menunjukan bahwa Bangsa Indonesia adalah bangsa yang memiliki kereligiusan yang tinggi dan menjunjung tinggi nilai-nilai agama dan ke-Tuhanan.

Berkaitan dengan hal tersebut maka dirasa penting bagi institusi penididikan dalam masyarakat yang multikultur untuk mengajarkan perdamaian dan resolusi konflik yang ada dalam masyarakat multikultural. Dan terlebih lagi bagi Pendidikan Agama Islam sebagai salah satu mata pelajaran yang dituntut mampu membawa kata perdamaian dalam setiap jiwa peserta didik (Erlan Muliadi, 2012).

Dengan demikian pada akhirnya semua kompetensi baik kognitif, afektif, dan psikomotor dapat dicapai dalam berbagai strategi yang dapat melibatkan peserta didik dalam belajar. Itulah hakikat dari salah satu gagasan besar dalam reformasi PAl di Indonesia yang memiliki keinginan untuk mengembangkan proses pembelajaran dengan prinsip baru, yaitu learning to do, learning to be, learning to learn, dan learning to live together. Dengan banyak melakukan teknik pembelajaran yang lebih banyak melibatkan siswa dalam proses pembelajaran tersebut, dan karena seringnya mereka melakukan kerjasama misalnya dalam bentuk satu kelompok kerja, maka hal itu dapat membentuk siswa 
memiliki sikap inklusif dan pluralis dalam kehidupan sehari-hari (Zainal Abidin, 2012).

Namun faktanya, sampai saat ini pendidikan agama yang diterapkan di sekolah selalu menanamkan pemahaman pada siswa bahwa agamanya paling benar, dan yang lainnya dianggap salah sehingga tumbuh dalam diri peserta didik sikap intoleran, serta adanya hubungan yang kurang harmonis antar umat beragama. Hal ini terjadi karena adanya kesalahan dari pendidik dalam mengajarkan tentang etiket dari suatu budaya tertentu sehingga memberikan dampak pada primordialisme kesukuan, agama, dan golongan.

Oleh karena hal tersebut, diperlukan penanaman nilai-nilai multikultural dalam pembelajaran Pendidikan Agama Islam. Melalui penanaman nilai-nilai multikultural peserta didik yang memiliki latar belakang berbeda akan dibimbing untuk saling mengenal agama, budaya, cara hidup, adat istiadat, serta diajak untuk memahami, mengakui dan menghormati bahwa tiap golongan memiliki hak untuk menyatakan diri menurut caranya masing-masing serta memahami Bhineka Tunggal Ika dan mengimplementasikannya dalam kehidupan sehari-hari. Dengan menanamkan nilai-nilai multikultural sejak masih kecil diharapkan anak mampu menerima serta memahami perbedaan budaya yang menyebabkan adanya perbedaan usage (cara individu dalam bertingkah laku), folkways (kebiasaan yang ada di masyarakat), mores (tata kelakuan di masyarakat), dan customs (adat istiadat suatu komunitas) (Yaya Suryana, 2015).

SMA Kharisma bangsa merupakan salah satu sekolah swasta bertaraf Internasional yang beralamatkan di Jl.Terbang layang, No. 21, Pondok cabe, Kota Tangerang Selatan. Hampir setiap tahunnya sekolah ini menjadi salah satu sekolah yang menjadi tujuan utama para pendaftar bukan hanya dari wilayah
Tangerang Selatan tetapi juga dari berbagai daerah lainnya bahkan para siswa dari berbagai negara yang tinggal di Indonesia. Di sekolah ini terdapat banyak siswa dari berbagai latar belakang ekonomi, sosial, suku dan agama. Namun pada kenyataannya perbedaan itu tidak menjadi halangan untuk mereka saling berinteraksi dan bergaul dengan baik serta hidup rukun. Kerukunan itu dapat dilihat dan diamati dari cara mereka berkomunikasi baik dengan guru maupun dengan warga sekolah lainnya. Kegiatan-kegiatan keagamaan pun dilakukan dengan melibatkan seluruh siswa tanpa memandang perbedaan budaya dan agamanya. Melihat kondisi tersebut peneliti ingin mengetahui bagaimana cara guru menanamkan nilai- nilai multikultural khususnya dalam pembelajaran Pendidikan Agama Islam. Dalam penelitian ini peneliti akan melihat dari segi materi Pendidikan Agama Islam apakah penanaman nilai-nilai multikultural dalam pembelajaran PAI di SMA memiliki pengaruh terhadap pengembangan kebangsaan siswa di SMA Kharisma Bangsa.

Berdasarkan

pemaparan-

pemaparan yang telah dilakukan diatas, penulis tertarik untuk melakukan penelitian tersebut dengan judul "Aktualisasi Nilai-nilai Multikultural dalam Pembelajaran PAI dalam kerangka Pengembangan Kebangsaaan terhadap Siswa di SMA Kharisma Bangsa".

\section{Metode}

$\begin{array}{ccc}\text { Dalam penelitian ini penulis } \\ \text { melakukan } & \text { penelitan } & \text { dengan }\end{array}$ menggunakan pendekatan kuantitatif. Penelitian kuantitatif yaitu penelitian yang dilakukan untuk mendapatkan jawaban dari permasalahan atau gambaran umum tentang suatu fenomena atau gejala yang dilandasi pada teori asumsi, selain itu juga dapat pula diartikan sebagai suatu pola pikir yang menunjukan hubungan antar 
variabel yang akan diteliti, mencerminkan jenis dan jumlah rumusan masalah yang perlu dijawab melalui penelitian, teori yang digunakan adalah untuk merumuskan hipotesis dan teknik analisis statistik yang akan digunakan.

Di samping itu metode yang dugunakan adalah korelasional deskriptif. Deskriptif suatu metode penelitian yang ditujukan untuk menggambarkan fenomena-fenomena yang ada, yang berlangsung pada saat ini atau saat yang lampau. Penelitian ini tidak mengadakan manipulasi atau pengubahan pada variabel-variabel bebas, tetapi menggambarkan suatu kondisi apa adanya (Nana Syaodih Sukmadinata, 2012).

Penelitian ini penulis arahkan pada kenyataan yang berhubungan dengan Aktualisasi Nilai-nilai Multikultural dalam Pembelajaran PAl dalam kerangka Pengembangan Kebangsaaan terhadap Siswa di SMA Kharisma Bangsa supaya mendapatkan data deskriptif berupa katakata tertulis yang disusun berdasarkan data lisan, perbuatan, dan dokumentasi yang diamati secara holistik dan bisa diamati secara konteks. Teknik pengumpulan data yang digunakan dalam penelitian ini berupa wawancara, observasi, angket dan dokumentasi.

Sedangkan sumber data dalam penelitian ini di klasifikasikan ke dalam 3 kelompok; yaitu 1) person (orang) merupakan sumber data yang bisa memberikan data berupa jawaban lisan melalui wawancara atau jawaban tertulis melalui angket, ucapan guru PAI, kepala sekolah, siswa-siswi dan pihak-pihak yang terkait. Dalam penelitian ini yang penulis wawancarai adalah kepala SMA, guru PAI dan para guru menjadi sumber data utama yang dituangkan melalui catatan tertulis, 2) place (tempat) Yaitu sumber data yang menyajikan tampilan berupa keadaan diam dan bergerak. Data yang berupa kondisi fisik SMA dan juga aktivitas yang dialami sehari-hari oleh seluruh komunitas yang ada di SMA Kharisma Bangsa menjadi sumber data pendukung yang diwujudkan melalui rekaman gambar (foto), dan 3) paper (berkas data) yaitu sumber data yang menyajikan tanda-tanda berupa huruf, angka, gambar, atau simbol-simbol lain. Sember data ini diperoleh dari buku-buku, dokumen, arsip, dan lain sebagainya. Data yang penulis kumpulkan dari SMA Kharisma Bangsa adalah data yang berkaitan dengan fokus penelitian.

\section{Hasil dan Pembahasan}

Berdasarkan hasil pengujian statistik dari angket yang diberikan kepada 70 orang siswa yang dijadikan sebagai responden menunjukan bahwasanya terdapat pengaruh yang signifikan dari penanaman nilai-nilai multikultural dalam pembelajaran PAI terhadap pengembangan kebangsaan siswa di SMA Kharisma Bangsa. Hal ini dibuktikan dengan hasil uji validitas dan realibitas yang dilakukan, dimana hanya terdapat 1 soal yang tidak valid pada variabel $X$ tepatnya pada soal nomor 11 . Selanjutnya hasil dari angket tersebut diidentifikasi dan dianalisis menggunakan uji prasyarat analisis data, diantaranya uji normalita, uji homogenitas, uji heteroskedastisitas, dan uji linearitas, sehingga kemudian dapat diketahui bahwa penanaman nilai- nilai multikultural dalam pembelajaran PAI memberikan pengaruh terhadap pengembangan kebangsaan. Hal ini dapat dibuktikan dengan perhitungan uji statistik yang menggunakan rumus " $r$ " yang selanjutnya diperoleh nilai $r$ hitung sebesar 0,240 setelah dikonsultasikan dengan " $r$ " pada taraf signifansi sebesar 0,235 dan selanjutnya diketahui bahwa $r$ hitung lebih besar dari $r$ tabel hal ini menunjukan bahwa hipotesis alternative (Ha) yang berbunyi "Terdapat pengaruh yang signifikan antara penanaman nilainilai multikultural dalam pembelajaran 
Jurnal Edumaspul, 5 (1), Year 2021 - 755 (Jimatul Arrobi, Mariana Panji Ramadan, Anjarsari)

Pendidikan Agama Islam terhadap pengembangan kebangsaan di SMA Kharisma Bangsa" diterima, sedangkan hipotesis nihil (Ho) yang berbunyi "Tidak terdapat pengaruh yang signifikan antara penanaman nilai-nilai multikultural dalam pembelajaran Pendidikan Agama Islam terhadap pengembangan kebangsaan di SMA Kharisma Bangsa" ditolak.

Selain daripada itu untuk memperkuat hasil dari uji statistik yang dilakukan, peneliti terlebih dahulu melakukan observasi dan wawancara. Dalam observasi yang dilakukan peneliti melakukan pengamatan di kelas 10 Oxford yang terdiri dari 12 orang siswi. Dalam pengamatan yang dilakukan terlihat bahwa kedisiplinan guru dan juga siswa sangat tinggi. Guru masuk tepat waktu, dan siswa sudah berada di kelas sebelum guru memasuki ruangan kelas. Selain itu penanaman nilai-nilai keagamaan di SMA Kharisma Bangsa sudah sangat baik. Hal ini terlihat dari pembiasaan membaca do'a sebelum pembelajaran berlangsung. Peneliti juga mengamati cara guru menyampaikan materi pelajaran dan metode yang digunakan. Peneliti mengamati bahwa dalam prakteknya Ibu Kharisma selaku guru PAl tidak hanya menggunakan metode ceramah, tetapi juga menggunakan metode sharing group dan lainnya yang menarik siswa dalam mengikuti kegiatan pembelajaran. Selain itu siswa juga berperan aktif dalam proses kegiatan belajar, siswa aktif bertanya dan menjawab setiap pertanyaan yang diajukan. Ibu Kharisma selaku gurupun selalu mengajak siswa untuk mengemukakan jawaban, pertanyaan dan pendapatnya. Hal ini menunjukan bahwasanya siswa dan siswi SMA Kharisma Bangsa susdah menerapkan nilai-nilai keagamaan dengan baik, selain itu juga guru memberikan wadah bagi siswa untuk bisa berbaur dengan siswa yang lainnya dalam proses pembelajaran yang dengan hal tersebut dapat melatih dan membiasakan siswa menghargai dan terbuka dalam menanggapi perbedaan yang ada.

Selanjutnya setelah melakukan observasi peneliti melakukan wawancara dengan guru mata pelajaran Agama atau PAI SMA Kharisma Bangsa yaitu Ibu Kharisma. Dalam wawancara tersebut peneliti ingin mengetahui bagaimana guru menyampaikan nilai-nilai multikultural yang terkandung dalam pembelajaran Agama atau PAl terhadap siswa SMA Kharisma Bangsa yang notabene memiliki keragamanan baik dari segi budaya (culture), agama sampai dengan suku bangsa. Dari wawancara tersebut peneliti mendapatkan informasi bahwasanya memang bukan materi mengenai multikultural langsung yang terkandung dalam pembelajaran Agama atau PAI tetapi lebih kepada output sikap dari pembelajaran materi tersebut. Selain itu Ibu Kharisma menuturkan bahwasanya penerapan nilai- nilai multikultural dalam pembelajaran PAI sangatlah perlu. Karena menurutnya masih banyak anak yang belum terbiasa dikenalkan dengan perbedaan. Perbedaan yang sedikit mencolok di SMA Kharisma bangsa adalah tentang perbedaan madzhab, dikarenakan banyak siswa yang berasal dari Turki dan Negara Timut Tengah lainnya. Guru sebagai pendidik haruslah mengerti dan memahami keberagaman yang ada itu sendiri, khususnya dalam pembelajaran Agama Islam, pemahaman guru haruslah mendalam sehingga dapat menjadikan siswa lebih mengerti banyak hal mengenai perbedaan dan menjadi lebih terbuka dan dapat menerima perbedaan yang ada Selanjutnya Ibu Kharisma juga menjelaskan mengenai metode yang biasa digunakan guru dalam pembelajaran PAI di SMA Kharisma Bangsa sangatlah beragam. Hal ini bertujuan agar siswa lebih tertarik dan bersemangat dalam mengikuti 
Jurnal Edumaspul, 5 (1), Year 2021 - 756 (Jimatul Arrobi, Mariana Panji Ramadan, Anjarsari)

kegiatan pembelajaran PAI. Biasanya guru menggunakan metode ceramah untuk beberapa materi yang memang lebih banyak membutuhkan penjelasan, terkadang juga menggunakan metode sharing/diskusi kelompok, drama dan lain sebagainya. Selain itu Ibu Kharisma menambahkan bahwasanya dalam menyampaikan materi yang dijadikan rujukan dan referensi bukan hanya buku wajib yang diberikan oleh pemerintah, tetapi juga banyak menggunakan bukubuku lain sebagai sumber rujukan, baik buku nasional, dan internasional, ataupun buku-buku mengenai Pendidikan Agama Islam yang berbahasa Inggris, Arab atau buku-buku lainnya yang menunjang pembelajaran. Hal tersebut menunjukah bahwa dalam prosesnya guru sudah memberikan fasilitas bagi siswa dan mewadahi mereka untuk lebih mengenal keberagaman dalam pembelajan PAI. Dalam hal ini Ibu Kharisma sudah berusaha untuk bersifat adil dan memberikan penjelasan yang mudah dipahami oleh siswa mengenai perbedaan yang ada di sekelilingnya, khusunya dalam perbedaan madzhab dan agama.

\section{Simpulan}

Berdasarkan pembahasan dan analisis terhadap penelitian tentang Aktualisasi Nilai-nilai Multikultural dalam Pembelajaran PAI dalam Kerangka Pengembangan Kebangsaan Terhadap Siswa di SMA Kharisma Bangsa, terdapat beberapa temuan yang dapat disimpulkan yaitu Hasil yang didapatkan dalam penelitian ini menunjukan bahwa terdapat pengaruh dengan nilai signifikan yang rendah antara penanaman nilai- nilai multikultural terhadap pengembangan kebangsaan siswa di SMA Kharisma Bangsa. Hal ini dibuktikan dengan diperolehnya nilai $r$ hitung sebesar $0,240, r$ tabel sebesar 0,235 dan termasuk kategori rendah ( $r$ hitung pada rentang 0,20 $-0,39$ ) dengan KD sebesar 5,7. Karena nilai $r$ hitung $>r$ tabel dengan demikian $\mathrm{Ha}$ diterima dan Ho ditolak, dari pemaparan hal tersebut dapat ditarik kesimpulan bahwa terdapat pengaruh yang signifikan anatara penanaman nilai-nilai multikultural dalam pembelajaran PAI terhadap pengembangan kebangsaan siswa di SMA Kharisma Bangsa dengan kontribusi yang diberikan hanya sebesar $5,7 \%$.

SMA Kharisma Bangsa memiliki visi, misi, tujuan dan nilai-nilai yang sangat menjunjung tinggi keberagaman (Kebhinekaan), Kharisma Bangsa juga sangat menjunjung tinggi dan merangkul semua perbedaan/keberagaman yang ada di lingkungan sekolah. Hal ini terbukti dari prinsip yang diterapkan, dan kultur yang ada di sekolah tersebut. Metode penanaman nilai-nilai multikultural di SMA Kharisma Bangsa menggunakan metode keteladanan dan pembiasaan yang sesuai dengan visi, misi, dan nilai-nilai Kharisma Bangsa, yakni keberagaman, unggul, tanggungjawab dan hormat.

Penanaman nilai-nilai multikultural dalam pembelajaran PAI terhadap siswa di SMA Kharisma Bangsa meliputi sikap saling toleran, saling menghormati, dapat menerima pendapat orang lain, saling bekerja sama, tidak bermusushan, serta tidak adanya konflik yang disebabkan oleh perbedaan budaya, suku, bahasa, adat istiadat, dan agama. Bentuk dari penanaman nilai-nilai multikultural bukan dalam bentuk materi mengenai multikultural yang ada di dalam buku ajar PAI, tetapi lebih kepada output dari hasil atau proses pembelajaran PAI itu sendiri.

Sehingga diperoleh kesimpulan bahwa terdapat hubungan yang signifikan antara penanaman nilai-nilai multikultural dengan pengembangan kebangsaan, dalam penelitian ini dapat diimplikasikan bahwa perlunya upaya guru PAI untuk turut serta dalam mengenalkan tentang nilai-nilai 
multikultural, agar siswa dapat lebih terbiasa dan dapat menerima perbedaan yang ada khususnya mengenai perbedaan agama. Selain itu guru juga harus memberikan contoh hidup untuk saling menghargai di lingkungan sekolah, maupun di lingkungan bermasyarakat.

\section{Daftar Pustaka}

[1] Alam, Lukis. (2016). Aktualisasi Pendidikan Islam dalam Keluarga (Perspektif Al-Qur'an Surat Luqman). Muaddib: Studi Kependidikan dan Keislaman.

https://core.ac.uk/download/pdf/20757 4928.pdf.

[2] Arikunto, Suharsimi. (2002). Prosedur Penelitian Suatu Pendekatan Praktik. Jakarta: Rineka Cipta.

[3] Aulia, Vivi \& Moh. Yamin. (2011). Meretas Pendidikan Toleransi: Pluralisme dan Multikulturalisme Sebuah Keniscayaan Peradaban. Malang: Madani Media.

[4] Azman. (2017). Nasionalisme dalam Islam. Jurnal Al-Daulah, 6(2). http://journal.uinalauddin.ac.id/index.php/al_daulah/arti cle/view/4881.

[5] Baidhawy, Zakiyuddin. (2005). Pendidikan Agama Berwawasan Multikultural. Jakarta: Erlangga.

[6] Departemen Agama RI. (2009). AlQur'an dan Terjemahannya. Bandung: Syamil Qur'an.

[7] Erwin, Muhammad. (2013). Pendidikan Kewarganegaraan Republik Indonesia. Bandung: Refika Aditama.

[8] Hamalik, Oemar. (1999). Kurikulum dan Pembelajaran. Jakarta: Bumi Aksara.

[9] Isna, Mansur. (2001). Diskursus Pendidikan Islam. Yogyakarta: Global Pustaka Utama.
[10] Juliardi, Budi. (2017). Pendidikan Kewarganegaraan untuk Perguruan Tinggi. Jakarta: PT. Rajagrafindo.

[11] Kartawisastra, Una. (1980). Strategi Klarifikasi Nilai. Jakarta: P3G Depdikbud.

[12] Lestariningsih, Wahyu Adya, et.al. (2018). Penanaman Nilai-nilai Multikultural dalam Pembelajaran Sejarah di SMA Negeri 1 Rembang Tahun Pelajaran 2017/2018. Indonesian Journal of History Education, 6(2). https://journal.unnes.ac.id/sju/index.ph $\mathrm{p} / \mathrm{ijhe} / \mathrm{article} / \mathrm{view} / 27636$.

[13] Ma'arif, Syamsul. (2006). Islam dan Pendidikan Pluralisme (Menampilkan Wajah Islam Toleran Melalui Kurikulum PAI Berbasis Kemajemukan). Bandung: Alfabeta.

[14] Ma'arif Syamsul. (2007). Revitalisasi Pendidikan Islam. Yogyakarta: Graha Ilmu.

[15] Martono, Nanang. (2014). Metode Penelitian Kuantitatif: Analisis Isi dan Analisis Data Sekunder. Jakarta: PT. Rajagrafindo.

[16] Maslikhah. (2007). Quo Vadis: Pendidikan Multikultural Rekonstruksi Sistem Pendidikan Berbasis Kebangsaan. Salatiga: STAI Salatiga Press.

[17] Muhaimin, et.al. (2012). Paradigma Pendidikan Agama Islam: Upaya Mengefektifkan Pendidikan Agama Islam di Sekolah. Bandung: PT. Remaja Rosdakarya.

[18] Muliadi, Erlan. (2012). Urgensi Pembelajaran Pendidikan Agama Islam Berbasis Multikultural di Sekolah. Jurnal Pendidikan Islam, 1(1). https://doi.org/10.14421/ipi.2011.11.55 -68.

[19] Mudzar, Atho. (2005). Meretas Wawasan dan Praktis Kerukunan Umat Beragama di Indonesia dalam Bingkai 
Jurnal Edumaspul, 5 (1), Year 2021 - 758

(Jimatul Arrobi, Mariana Panji Ramadan, Anjarsari)

Masyarakat Multikultural. Jakarta: Puslitbang Kehidupan Beragama.

[20] Nata, Abudin. (2007). Paradigma Pendidikan Islam. Jakarta: Grasindo.

[21] Peraturan Pemerintah Republik Indonesia Nomor. 55 Tahun2007 tentang Pendidikan Agama dan Keagamaan.

[22] Samrin. (2015). Pendidikan Agama Islam dalam Sistem Pendidikan Nasional di Indonesia. Al-Ta'dib: Jurnal Kajian IImu Pendidikan.

https://ejournal.iainkendari.ac.id/index. php/al-tadib/article/view/395/379.

[23] Ramayulis. (2012). Ilmu Pendidikan Islam. Jakarta: Kalam Mulia.

[24] Sani, Ahmad Faiz Ibnu. (2019). NU Usul Sebut kafir ke Non Muslim Indonesia Dihapus. Tempo Nasional.

[25] Saubani, Andri. (2019). Said Aqil Jelaskan Perbedaan Kafir dan NonMuslim. Khazanah Republika.

[26] Sudijono, Anas. (2011). Pengantar Statistik Pendidikan. Jakarta: PT. Rajagrafindo Persada.

[27] Sugiyono. (2010). Penelitian Pendidikan. Bandung: Alfabeta.

[28] Sukmadinata, Nana Syaodih. (2012). Metode Penelitian Pendidikan. Bandung: PT. Remaja Rosdakarya.

[29] Suparman, Heru. (2017). Multikultural dalam Perspektif Al Qur'an. Jurnal Studi Al-Qur'an dan Hadis, 1(2). http://repository.uinjkt.ac.id/dspace/ha ndle/123456789/48212.

[30] Suryana, Yaya. (2015). Pendidikan Multikultural Suatu Upaya Penguatan Jati Diri Bangsa: Konsep, Prinsip, dan Implementasi. Bandung: Pustaka Setia.

[31] Suryani \& Hendryadi. (2015). Metode Riset Kuantitatif: Teori dan Aplikasi pada Penelitian Bidang Manajemen dan Ekonomi Islam. Jakarta: Prenada Media Group.

[32] Syam, Mohammad Nur. (1986). Pendidikan Filsafat dan Dasar Filsafat Pendidikan. Surabaya: Usaha Nasional.

[33] Syeirazi, M. Kholid. (2019). Non-Muslim Bukan Kafir, NU Online.

[34] Thoha, M. Chatib. (2006). Kapita Selekta Pendidikan Islam. Yogyakarta: Pustaka Pelajar.

[35] Tim Penyusun KBBI. (2005). Kamus Besar Bahasa Indonesia (KBBI). Jakarta: Balai Pustaka.

[36] Uhbiyati, Nur. (1998). Ilmu Pendidikan Islam. Bandung: CV. Pustaka Setia.

[37] Purwadaminta, W.J.S. (1999). Kamus Umum Bahasa Indonesia. Jakarta: Balai Pustaka.

[38] Winarno. (2017). Paradigma Baru Pendidikan Kewarganegaraan: Panduan Kuliah di Perguruan Tinggi. Jakarta: Bumi Aksara.

[39] Yusuf, Choirul Fuad. (2008). Pendidikan Agama Berwawasan Kerukunan. Jakarta: PT. Pena Citra Satria. 